How to cite this article:

Bhatti, A., \& Ur Rahman, S. (2019). Perceived benefits and perceived risks effect on online shopping behavior with the mediating role of consumer purchase intention in Pakistan. International Journal of Management Studies, 26(1), 33-54.

\title{
PERCEIVED BENEFITS AND PERCEIVED RISKS EFFECT ON ONLINE SHOPPING BEHAVIOR WITH THE MEDIATING ROLE OF CONSUMER PURCHASE INTENTION IN PAKISTAN
}

\author{
ANAM BHATTI ${ }^{*}$ \\ ${ }^{1}$ PhD Student, School of Business Management, \\ Universiti Utara Malaysia \\ SHAFIQUE UR REHMAN ${ }^{2}$ \\ ${ }^{2}$ PhD Student, Tunku Puteri Intan Safinaz School of Accountancy, \\ Universiti Utara Malaysia \\ *Corresponding Author: gujranwalaanam091@gmail.com
}

\begin{abstract}
The purpose of this study is to examine the relationship between different factors including perceived benefits, perceived risks and online shopping behavior with the mediating role of consumer purchase intention. Online shopping states the recent trends of being able to purchase anything from home with a single click. The main focus of this study is to check the influence of four major variables: convenience, product variety, product risk, and privacy risk which were derived from related literature. Data were collected from 384 students from different universities using simple random sampling. PLS-SEM was used in this study and the results showed that benefits had a positive influence and that risk had a negative influence on online shopping behavior.
\end{abstract}

Keywords: Perceived benefits, perceived risks, consumer purchase intention, online shopping behavior.

Received: 23/1/2019 Revised: 13/11/2019 Accepted: 30/12/2019 Published: 31/1/2020 


\section{Introduction}

Online shopping allows the consumer to buy directly from the seller without any third person on an Internet browser. In the last twenty years, online shopping has played a significantly important role and more than 1.6 billion people in the whole world purchase goods online and this system has generated 1.90 trillion US dollars in 2016 (Rehman, Bhatti, Mohamed, \& Ayoup, 2019). Moreover, online shopping popularity is growing day by day, because people perceive that online shopping is more convenient as they can shop from their home. It also provides detailed information about a product with a single click of the mouse. Consumer behavior matters when individuals or groups choose, buy, evaluate and use products and services. There are various factors that affect online shopping and consumer behavior as well; these factors may be perceived risks like product risk and privacy risk and perceived benefits like convenience and product comparison. No doubt the Internet has facilitated consumers. Despite these benefits, there are perceived risks in the consumers' mind that may pose an obstacle between consumer intention and behavior. This is the main reason why online shopping in Pakistan is very low and consumer acceptance is the most challenging task for online vendors (Bhatti, 2018). Risk perception was introduced in consumer behavior and in marketing terms in the early 60 s and online shopping concept was introduced in the early 1990s (Bauer, 1960).

Different factors affect online shopping behavior and these factors include perceived risks and benefits. Consumer purchase intention is a significant sign from consumers (Bhatti, 2018b; 2018c). In Pakistan, e-commerce is still at the introductory stage and is relatively low as compared to developed and other developing countries (Yousaf, Altaf, Sarwar, Hassan, \& Ali, 2012). According to survey, Pakistan is the second to last country in online shopping due to various risks, inaccessibility of the Internet, low levels of education, and lack of awareness (Nielsen, 2008). In Pakistan, only 3 percent of the whole population buy online and the current e-commerce market is around \$70-150 million which is expected to grow $\$ 1$ billion by 2020 . Furthermore, Pakistan's e-commerce market is not near to 0.1 percent of its total retail sales but in other countries, this ratio is very high, for instance, China e-commerce sales accounted for 18-20 percent of total retail sales and US e-commerce sales recorded 8-9 percent of total retail sales (Pakwired, 2017, July 20). 
Many studies directed online shopping behavior but it is still a big challenge and needs to study and focus on online shopping behavior in Pakistan (Bhatti, 2018; Qureshi, Fatima, \& Sarwar, 2014). The main purpose of this study is to examine the various factors like perceived benefits and perceived risks which influence online shopping behavior in Pakistan. By reducing the risks and enhancing the benefits we can increase online shopping in Pakistan.

\section{Perceived Benefits}

\section{Literature Review}

The Internet presents some risk in online shopping but it also gives many advantages that changes consumer perception to buy online. The perceived benefits are consumer belief and satisfaction with online transactions and consumer perception that online shopping is convenient, easy, more product variety and less risky as compared to conventional shopping.

\section{Convenience}

The Internet makes our life easy and we can do a quick search for our desired product within seconds and therefore can buy anything easily. According to Seiders, Berry and Gresham (2000) convenience provides four opportunities in the buying process: access, search, possession, and transaction. Furthermore, convenience is a major predictor prompting consumers to shop online (Ahmad, 2002; Jayawardhena, Tiu Wright \& Dennis, 2007). Moreover, convenience is an important predictor regarding online buying willingness (Wang, Zhang, Ye \& Nguyen, 2005). Consumers do not need to go to the market and do not need to leave their home and with globalization, they are not bound at home by time constraints and they can buy anything any time because online shopping provides 24 hours service (To, Liao, \& Lin, 2007). Previous studies have shown a positive relationship between convenience and online shopping behavior (Adnan, 2014; Bashir, Mehboob \& Bhatti, 2015; Chaudary, Rehman \& Nisar, 2014; Dost, Khyzer, Illyas \& Abdul Rehman, 2015; Suhan, 2015). On the other hand, some researchers have shown that convenience has a strong influence on online shopping behavior (Rehman, 2018). Thus, the relationship between convenience and online shopping behavior is not clear and there is a need to add another variable that explains 
this relationship better. In the current study, consumer purchase intention mediates the relationship between convenience and online shopping behavior.

$\mathrm{H}_{1}$ : Convenience has a positive influence on online shopping behavior.

$\mathrm{H}_{2}$ : Consumer purchase intention significantly mediates the relationship between convenience and online shopping behavior.

\section{Product Variety}

Online shopping provides more benefits and convenience as compared to conventional shopping. In conventional shopping, the customer physically visits shops; one by one which wastes time and today, not everyone has much time to visit the shops anymore. Therefore, the Internet provides multiple options to consumers and they can easily search, evaluate, compare a product with multiple brands and product variety from their home without physically visiting shops and they can place their order via the Internet and get the desired products and services sent to their home. According to To et al. (2007) online websites provide a wide variety of brands for consumer selection. There are no online store limits for stock and also no necessity for window displays. The wider variety is the main reason that motivates consumers to buy online. It is very convenient for consumers who buy regularly and they can get variety easily (Sin \& Tse, 2002). Product variety is the main factor that prompts consumer attention, motivates them and generates intention to buy online. Previous studies have shown that there is a significant positive relationship between product variety and online shopping behavior (Adnan, 2014; Kim \& Ammeter, 2018). Nevertheless, the relationship between product variety and online shopping behavior is not clear. Therefore, there is a need for another variable to explain this relationship more clearly. In this study consumer purchase intention is used as a mediator to explain the relationship between product variety and online shopping behavior.

$\mathrm{H}_{3}$ : Product variety has a positive influence on online shopping behavior.

$\mathrm{H}_{4}$ : Consumer purchase intention significantly mediates the relationship between product variety and online shopping behavior. 


\section{Perceived Risk}

Perceived risk is defined by Dowling and Staelin (1994) as "the consumer's perception of the uncertainty and adverse consequences of buying a product or service". Perceived risk in consumer behavior and marketing studies in the early 60s (Bauer, 1960), and in the concept of online shopping introduced in the 1990s (Mitchell, 1999) and many other studies on perceived risk have shown that perceived risk has a negative effect on the online shopping behavior of consumers (Adnan, 2014).

\section{Product Risk}

Product risk is the failure to meet predictable performance or a product ordered did not meet its expected function. Product risk is high in online shopping due to the inability to take a look at physical products and also, they cannot be tested. On the other hand, in conventional shopping the consumer can see the physical product and can also test it. Therefore, the risk in conventional shopping is minimal compared to online shopping. This is a major problem for the consumer. In online shopping, consumers have some information about the product, so they rely on this limited information to examine the quality of the product (Popli \& Mishra, 2015). Research has shown that product risk negatively influences online shopping behavior (Bhatti, 2018; Chakraborty, 2016). Meanwhile, product risk discourages consumers to buy. Once consumers encounter a negative experience, it would critically affect the confidence and satisfaction level of the consumers. Privacy risk also includes financial damages because consumers think that they can be cheated and lose money through online shopping (Crespo, del Bosque, \& de los Salmones Sanchez, 2009). Product risk is the most problematic risk to consumer behavior. If the online retailer controls product risk and ensures the consumer regarding product quality and performance then online shopping can enhance sales. Hence, in the future, focus should be on product risk (Rehman, 2018). Despite this, literature has revealed that product risk has no influence on online shopping behavior (Bhatti, Saad, \& Gbadebo, 2018a). Thus, the relationship between product risk and online shopping behavior is not clear and there is a need to add another variable that explains this relationship more clearly. The current study used a mediator that is, consumer purchase intention to explain further the relationship between product risk and online shopping behavior. 
$\mathrm{H}_{5}$ : Product risk has a negative influence on online shopping behavior.

$\mathrm{H}_{6}$ : Consumer purchase intention significantly mediates the relationship between product risk and online shopping behavior.

\section{Privacy Risk}

Privacy risk is the most prominent risk and is an issue in purchasing on the Internet. In online shopping, consumers need to disclose their personal information in online transactions. Furthermore, with the growth of online shopping, privacy risk is also growing among consumers and due to this privacy issue consumers are reluctant to buy online. In Pakistan only 3 percent of people buy online that is increased by 2.07 percent in which 95 percent of the people use cash on delivery due to risks and they do not want to share their personal information on websites. According to Tanadi, Samadi and Gharleghi (2015), 8 percent of Internet users left online shopping due to privacy risk and 54 percent of the people never try to buy online as they believed that online shopping is a risk and dangerous for them and they could get into trouble. Privacy risk concern was habitually cited as the purpose for not purchasing online. Furthermore it does not significantly influence consumer intentions to purchase and consumer behavior. Consumer insecurity about a product leads to negative effects on intentions. Consumer intention to purchase online can be increased by ensuring that personal information of the consumer is secure, safe and confidential as it can enhance consumer intention to buy and ultimately enhance the online shopping behavior of consumers. Few studies have shown that privacy risk significantly reduces online shopping behavior (Aijaz \& Butt, 2009; Chaudary et al., 2014). In contrast, literature has demonstrated that privacy risk has no influence on online shopping behavior (Brüseke, 2016). Thus, the relationship between privacy risk and online shopping is not clear and needs to be studied further with the help of another variable that explains this relationship more clearly. In the current study, consumer purchase intention is used as a mediator to explain further the relationship between privacy risk and online shopping behavior. Moreover, previous studies have shown that in future there is a need to conduct more in-depth studies on privacy risk and online shopping behavior (Bhatti, 2018; Bhatti, 2018a; Rehman, 2018).

$\mathrm{H}_{7}$ : Privacy risk has a negative influence on online shopping behavior. 
$\mathrm{H}_{8}$ : Consumer purchase intention significantly mediates the relationship between privacy risk and online shopping behavior.

\section{Consumer Purchase Intention and Online Shopping Behavior}

Consumer purchase intention is an individual plan to buy products or services in future, the purchase intention of consumers is influenced by many factors that is factors which benefit like convenience and product variety or it might be risks like product risk and privacy risk (Gregoire, 2013; Hidayanto, Saifulhaq \& Handayani, 2012). Lack of consumer purchase intention is a major problem in e-commerce and consumer purchase intention is a substitute of buying behavior that needs to be explored as purchase intention is an important predictor of online shopping behavior (He, Lu \& Zhou, 2008; Laohapensang, 2009). Furthermore, intentions are supposed to be a sign as to what level people are willing to approach certain behavior (Ajzen, 1991). In addition, the lack of intention is the main obstacle in the development of online shopping behavior (He et al., 2008). Meanwhile, risks and benefits influence intentions and intentions are the silent predictors of behavior and they ultimately influence the actual behavior of consumers. Many studies have shown a significant positive relationship between consumer purchase intention and online shopping behavior (Chih \& Tang, 2005; He et al., 2008; Kim, Ferrin \& Rao, 2008; Laohapensang, 2009; Pavlou, Liang \& Xue, 2006).

Several studies suggested that there is a need to study consumer purchase intention which is used as a mediator in online shopping behavior (Bhatti, 2018). Previous studies have shown that there is need to focus on online shopping behavior in future (Bhatti, Saad \& Gbadebo, 2018b; Chen \& Zimitat, 2006; Van der Heijden, Verhagen \& Creemers, 2003).

$\mathrm{H}_{9}$ : Consumer purchase intention has a significant influence on online shopping behavior.

\section{Theory of Planned Behavior}

This study's framework is based on the theory of planned behavior. In previous studies the theory of planned behavior (TPB) is usually used to study individual behavior and individual intentions. Basically, TPB is derived from the theory of reason action (TRA). According to TRA, individual intentions are based on attitude and subjective norms but 
TPB added some additional and fundamental factors such as perceived behavioral control and according to TPB it affects the intentions of the individual's behavior for online shopping. Furthermore, intentions affect behavior and controls consumer decision to conduct actual online shopping (Ajzen, 1985). TPB is the best theory to understand consumer behavior but is still not perfect and still a huge challenge for future researchers. Additionally, the researchers agree that there are many factors other than those included in TPB model which can affect the intentions and behavior of consumers. Therefore this research studied other predictors of perceived benefits and perceived risks to improve understanding of consumer behavior which delineates purchasing decision in online stores. According to (LaMorte, 2016) TPB ignores many predictors that may affect intentions and behavior of individuals such as fear, and threat. We studied perceived risks and perceived benefits to enhance the understanding of intentions and behavior because benefits and risks both influence consumer behavior. According to TPB, 62 percent of intentions explain behavior and 38 percent of the other variables affect consumer behavior so, there is a need to identify other variables that increase intention and ultimately affect behavior.

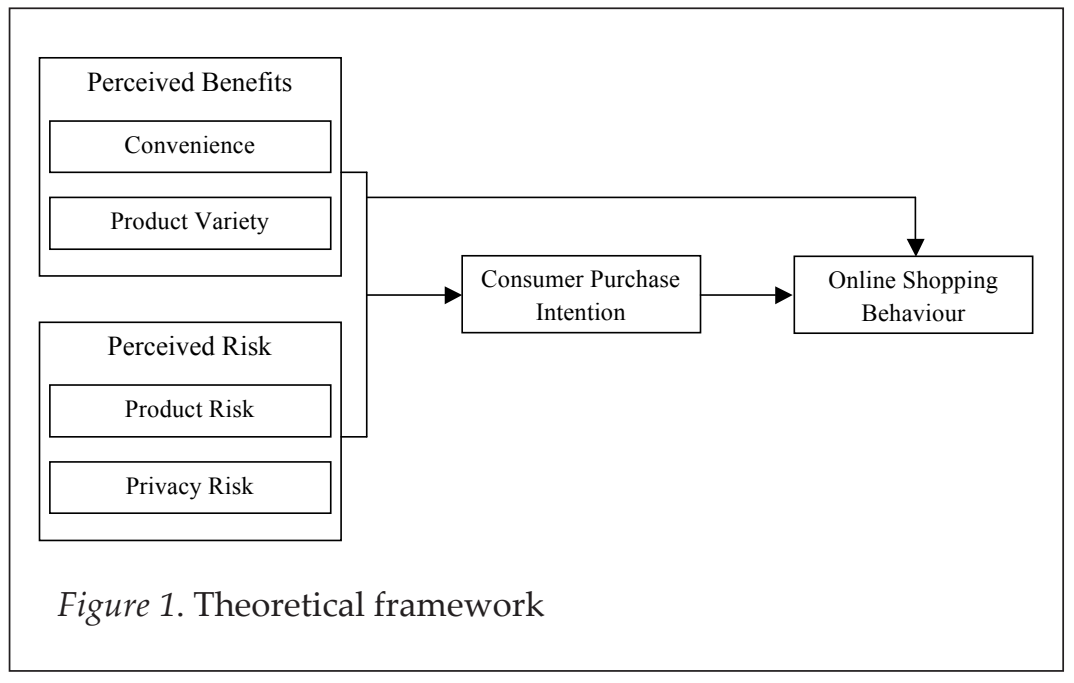

\section{Methodology}

A research design is an arrangement, strategy, and structure with the intention of getting to the solution of the research problem. This 
area is attractive for researchers and they focus on the methodology part to examine the objectives of the research (Rehman, Mohamed \& Ayoup, 2019). Moreover, the researchers confirmed that appropriate analysis techniques are needed to achieve research objectives and attempts to solve both theoretical and practical problems (Rehman et al., 2019). Thus, the current research on the nature, research problem, and research objectives used a quantitative approach to collect data from the respondents.

Online assessment was used to evaluate respondents' online shopping behavior and two perceived benefits (convenience and product variety), as well as two perceived risks (product risk and privacy risk), were considered for assessment. A self-administrated questionnaire was designed after critically evaluating the literature and summaries of all items on perceived benefits, perceived risks and online shopping behavior. The data was collected via a personal survey on online shopping behavior in Pakistan by distributing questionnaires based on simple random sampling because this sampling provides generalized results. It also manages the budget. The current study sample size was 384 in accordance with Roscoe's (1975) study. This study was descriptive in nature and the target population comprised male and female students of more than 18 years old, from Pakistani universities who were familiar with the computer and the Internet and have had online shopping experience. This study used a deductive approach. This study adopted items from previous studies to measure the constructs on online shopping behavior with 17 items that was adopted from Moshrefjavadi, Dolatabadi, Nourbakhsh, Poursaeedi and Asadollahi (2012), product risk consisted of three items (Moshrefjavadi et al., 2012), three items on privacy risk (Dai, Forsythe \& Kwon, 2014), three items on consumer purchase intention (Thananuraksakul, 2007), and three items on convenience (Clemes, Gan \& Zhang, 2014).

\section{Demographic Profile}

As shown in Table 1, the total number of respondents was $384(10.7 \%)$ respondents were female and $343(89.3 \%)$ respondents were male. In terms of qualifications, 15 (3.9\%) of the respondents had diplomas, $64(16.7 \%)$ had bachelor degrees, $263(68.5 \%)$ had master's degrees, 6 $(1.6 \%)$ had doctorate degrees and $36(9.4 \%)$ were other respondents. 
IJMS 26 (1), 33-54 (2019)

Table 1

Profile of Respondents

\begin{tabular}{lrc}
\hline \multicolumn{1}{c}{ Variable } & Frequency & Percentage \\
\hline \multicolumn{1}{c}{ Gender } & & \\
\hline Female & 41 & 10.7 \\
Male & 343 & 89.3 \\
\hline \multicolumn{1}{c}{ Qualification } & & \\
\hline Diploma & 15 & 3.9 \\
Bachelor degree & 64 & 16.7 \\
Master's degree & 263 & 68.5 \\
PhD degree & 6 & 1.6 \\
Others & 36 & 9.4 \\
\hline
\end{tabular}

\section{Statistical Analysis Results}

This study used PLS-SEM technique for analysis purposes because it was considered as the best for all types of models. There is a need to compute two models such as the measurement model and structural model.

\section{Measurement Model}

The measurement models measured the three types of validity: content, discriminant, and convergent validity (Hair, Ringle \& Sarstedt, 2013).

\section{Content Validity}

Content validity refers to a situation where loadings of a specific construct are greater than other construct items in the same row and column (Rehman et al., 2019). This study computes content validity through cross-loadings as recommended by Chin (1998) and Hair, Black, Babin and Anderson (2010). Table 2 demonstrates that this study fulfills the content validity criterion as suggested by Hair et al. (2013). 
IJMS 26 (1), 33-54 (2019)

\section{Convergent Validity}

Convergent validity means the level to see that all items of a construct measures the specific construct(s) (Rehman et al., 2019). Convergent validity measures three things: average variance-extracted (AVE), factor loadings, and composite reliability (CR) as suggested by Hair Jr, Hult, Ringle and Sarstedt (2013). To get the best results for CR and AVE in order to eliminate all items that were below 0.50 -factor loading. In this study CR. Table 3 demonstrates that this study fulfilled AVE and factor loading criterion.

Table 2

Cross Loadings

\begin{tabular}{lcccccc}
\hline Item & CPI & C & OSB & PR & PDR & PDV \\
\hline CPI1 & 0.864 & 0.405 & 0.348 & -0.164 & -0.075 & 0.402 \\
CPI2 & 0.876 & 0.407 & 0.349 & -0.214 & -0.073 & 0.387 \\
CPI3 & 0.845 & 0.564 & 0.408 & -0.129 & -0.075 & 0.382 \\
C1 & 0.467 & 0.888 & 0.368 & -0.078 & 0.178 & 0.477 \\
C2 & 0.512 & 0.927 & 0.375 & -0.091 & 0.038 & 0.540 \\
C3 & 0.482 & 0.894 & 0.387 & -0.095 & 0.018 & 0.559 \\
OSB1 & 0.296 & 0.337 & 0.721 & -0.121 & -0.010 & 0.306 \\
OSB10 & 0.357 & 0.412 & 0.828 & -0.153 & -0.079 & 0.384 \\
OSB11 & 0.367 & 0.262 & 0.783 & -0.116 & -0.097 & 0.290 \\
OSB12 & 0.282 & 0.295 & 0.687 & -0.137 & -0.082 & 0.311 \\
OSB14 & 0.379 & 0.381 & 0.805 & -0.149 & -0.095 & 0.398 \\
OSB16 & 0.248 & 0.229 & 0.675 & -0.120 & 0.013 & 0.270 \\
OSB17 & 0.268 & 0.274 & 0.635 & -0.081 & 0.030 & 0.303 \\
OSB2 & 0.306 & 0.286 & 0.787 & -0.115 & -0.041 & 0.267 \\
OSB3 & 0.231 & 0.223 & 0.691 & -0.123 & -0.056 & 0.165 \\
OSB6 & 0.239 & 0.218 & 0.620 & -0.107 & -0.095 & 0.214 \\
OSB8 & 0.394 & 0.327 & 0.715 & -0.131 & -0.100 & 0.251 \\
PR1 & -0.182 & -0.111 & -0.114 & 0.867 & -0.006 & -0.076 \\
PR2 & -0.137 & -0.111 & -0.175 & 0.862 & -0.004 & -0.106 \\
PR3 & -0.161 & -0.008 & -0.102 & 0.743 & 0.004 & -0.052 \\
PDR1 & -0.076 & 0.061 & -0.094 & -0.009 & 0.891 & 0.054 \\
PDR2 & -0.065 & 0.087 & -0.030 & 0.006 & 0.836 & 0.103 \\
PDR3 & -0.083 & 0.082 & -0.073 & -0.000 & 0.897 & 0.071 \\
PDV1 & 0.483 & 0.363 & 0.429 & -0.063 & 0.017 & 0.882 \\
PDV2 & 0.405 & 0.465 & 0.385 & -0.085 & 0.063 & 0.884 \\
PDV3 & 0.197 & 0.291 & 0.144 & -0.063 & 0.137 & 0.696 \\
PDV4 & 0.171 & 0.279 & 0.151 & -0.124 & 0.141 & 0.651 \\
\hline & & & & & &
\end{tabular}


IJMS 26 (1), 33-54 (2019)

\section{Discriminant Validity}

Discriminant validity refers to a condition where the researchers see that every indicator of a theoretical model is different in terms of statistics (Rehman et al., 2019). In this study, discriminant validity is measured on recommendations of Fornell and Larcker (1981a). Discriminant validity could be computed by using one of the methods. First, AVE square root values were compared with correlation values. Second, AVE was compared with squared correlations. This study used the first method to compute discriminant validity. AVE square root value in the upper diagonals must be higher than other values in similar rows and columns.

Table 3

Factor Loadings, Average Variance Extracted (AVE), and Composite Reliability (CR)

\begin{tabular}{|c|c|c|c|c|c|c|}
\hline Variable & Item & $\begin{array}{l}\text { Factor } \\
\text { Loading }\end{array}$ & AVE & CR & $\begin{array}{c}\text { Cronbach's } \\
\text { Alpha }\end{array}$ & $\mathrm{R} 2$ \\
\hline Convenience & $\begin{array}{l}\text { C1 } \\
\text { C2 } \\
\text { C3 }\end{array}$ & $\begin{array}{l}0.888 \\
0.927 \\
0.894\end{array}$ & 0.815 & 0.930 & 0.886 & \\
\hline $\begin{array}{l}\text { Product } \\
\text { Variety }\end{array}$ & $\begin{array}{l}\text { PDV1 } \\
\text { PDV2 } \\
\text { PDV3 } \\
\text { PDV4 }\end{array}$ & $\begin{array}{l}0.882 \\
0.884 \\
0.696 \\
0.651\end{array}$ & 0.617 & 0.864 & 0.814 & \\
\hline Product Risk & $\begin{array}{l}\text { PDR1 } \\
\text { PDR2 } \\
\text { PDR3 }\end{array}$ & $\begin{array}{l}0.891 \\
0.836 \\
0.897\end{array}$ & 0.766 & 0.907 & 0.852 & \\
\hline Privacy Risk & $\begin{array}{l}\text { PR1 } \\
\text { PR2 } \\
\text { PR3 }\end{array}$ & $\begin{array}{l}0.867 \\
0.862 \\
0.743\end{array}$ & 0.683 & 0.865 & 0.765 & \\
\hline $\begin{array}{l}\text { Consumer } \\
\text { Purchase } \\
\text { Intention }\end{array}$ & $\begin{array}{l}\text { CPI1 } \\
\text { CPI2 } \\
\text { CPI3 }\end{array}$ & $\begin{array}{l}0.864 \\
0.876 \\
0.845\end{array}$ & 0.743 & 0.896 & 0.827 & 0.357 \\
\hline
\end{tabular}

(continued) 
IJMS 26 (1), 33-54 (2019)

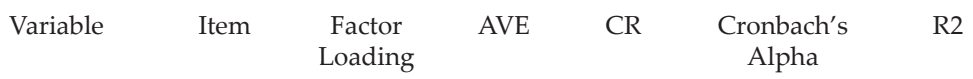

\begin{tabular}{lcccccc}
\hline & & & & & \\
& OS1 & 0.721 & & & \\
& OS10 & 0.828 & & & \\
& OS11 & 0.783 & & & \\
Online & OS12 & 0.687 & & & \\
Shopping & OS14 & 0.805 & & & \\
Behavior & OS16 & 0.675 & 0.526 & 0.924 & \\
& OS17 & 0.635 & & & \\
& OS2 & 0.787 & & & \\
& OS3 & 0.691 & & & \\
& OS6 & 0.620 & & & \\
& OS8 & 0.715 & & & \\
\hline
\end{tabular}

Table 3 proves the necessary standards for $\mathrm{CR}$ (greater than 0.60 ) and AVE (0.50)(Hair et al., 2013). According to Nunnally (1978), the value of Cronbach's alpha must be 0.70 or higher than 0.70 and this study met the criteria.

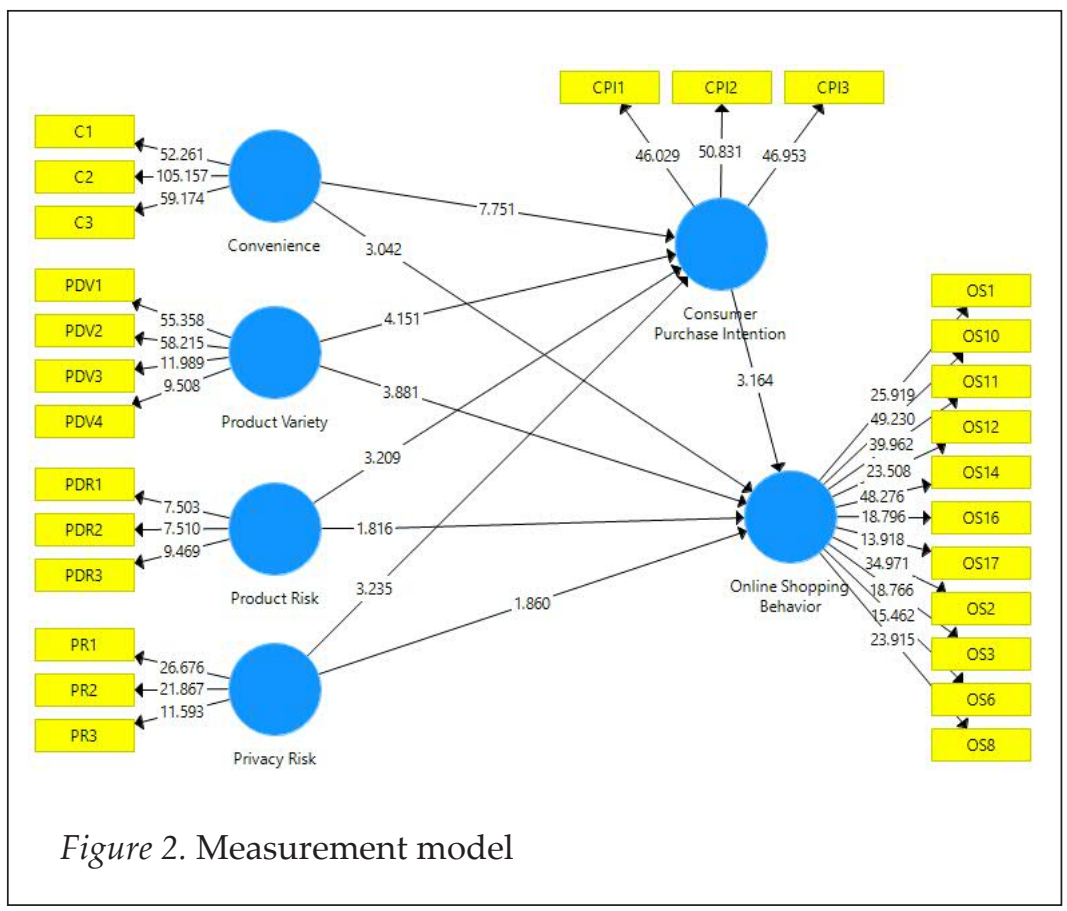


IJMS 26 (1), 33-54 (2019)

Table 4

Discriminant Validity (Fornell-Larcker)

\begin{tabular}{lcccccc}
\hline Variable & CPI & C & OSB & PR & PDR & PDV \\
\hline CPI & 0.862 & & & & & \\
C & 0.540 & 0.903 & & & & \\
OSB & 0.403 & 0.417 & 0.726 & & & \\
PR & -0.194 & -0.098 & -0.0171 & 0.826 & & \\
PDR & -0.086 & 0.085 & -0.081 & -0.003 & 0.875 & \\
PDV & 0.453 & 0.583 & 0.406 & -0.096 & 0.081 & 0.786 \\
\hline
\end{tabular}

Table 4 validates the standard of discriminant validity as proposed by Fornell and Larcker (1981b).

Table 5

Heterotrait-Monotrait Ratio (HTMT)

\begin{tabular}{lcccccc}
\hline Variable & CPI & C & OSB & PR & PDR & PDV \\
\hline CPI & & & & & \\
C & 0.620 & & & & \\
OSB & 0.484 & 0.454 & & & \\
PR & 0.247 & 0.114 & 0.202 & & \\
PDR & 0.101 & 0.113 & 0.105 & 0.033 & \\
PDV & 0.479 & 0.614 & 0.394 & 0.132 & 0.141 \\
\hline
\end{tabular}

Table 5 demonstrates that Heterotrait-Monotrait Ratio (HTMT) fulfills the threshold value as recommended by Hair et al. (2013).

\section{Assessment of Structural Model}

The direct and indirect hypotheses are discussed here. This study has five direct hypotheses and four mediating hypotheses. Substantial standards of loadings and path-coefficient authors suggested that bootstrap be performed with 5000 subsamples (Hair Jr, Hult, Ringle, \& Sarstedt, 2016). Table 6 indicates the results of the structural model. 
IJMS 26 (1), 33-54 (2019)

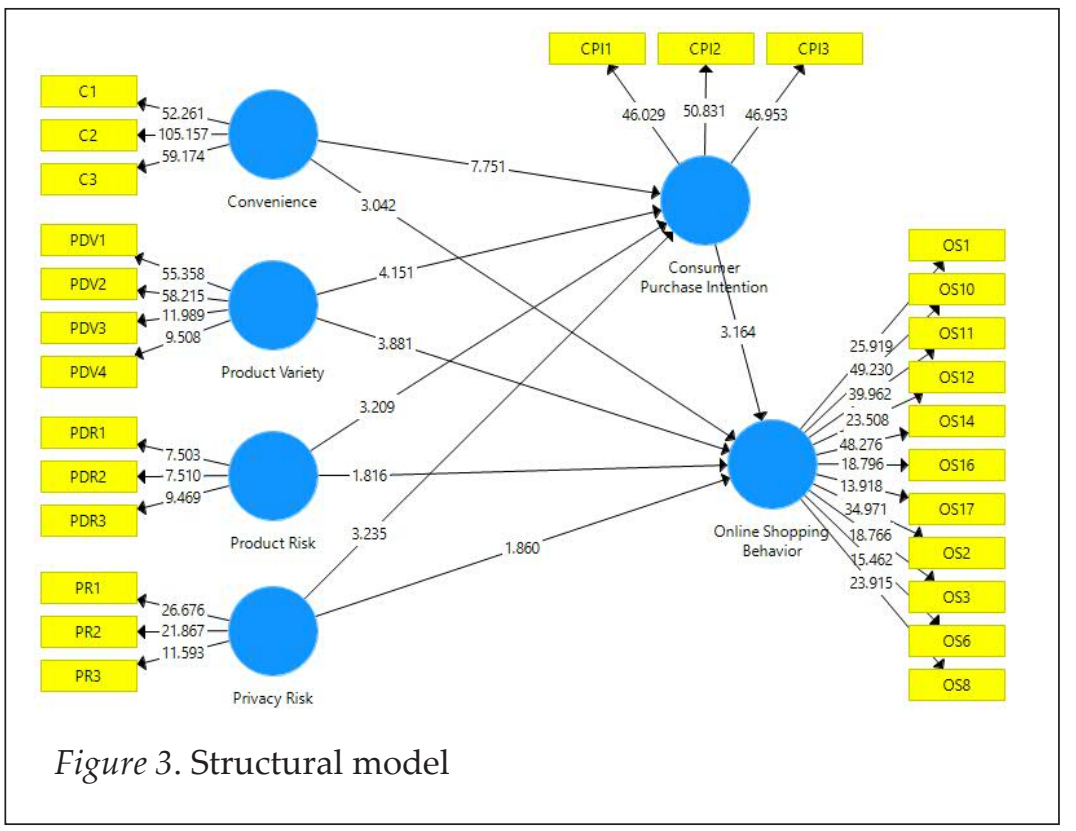

Table 6

Direct Relationships

\begin{tabular}{ccccccc}
\hline Hypotheses & Paths & $\begin{array}{c}\text { Path } \\
\text { co-efficient }\end{array}$ & $\begin{array}{c}\text { Standard } \\
\text { deviation }\end{array}$ & $t$-values & $p$-values & Results \\
\hline H1 & C --> OSB & 0.183 & 0.060 & 3.042 & 0.001 & Supported \\
H2 & C --> CPI -> OSB & 0.090 & 0.030 & 2.994 & 0.002 & Supported \\
H3 & PDV--> OSB & 0.201 & 0.052 & 3.881 & 0.000 & Supported \\
H4 & PDV --> CPI --> OSB & 0.045 & 0.018 & 2.448 & 0.014 & Supported \\
H5 & PR -> OSB & -0.093 & 0.050 & 1.860 & 0.032 & Supported \\
H6 & PR --> CPI --> OSB & -0.029 & 0.014 & 2.097 & 0.036 & Supported \\
H7 & PDR--> OSB & -0.095 & 0.052 & 1.816 & 0.035 & Supported \\
H8 & PDR --> CPI --> OSB & -0.030 & 0.013 & 2.215 & 0.026 & Supported \\
H9 & CPI --> OSB & 0.214 & 0.068 & 3.164 & 0.001 & Supported \\
\hline
\end{tabular}

Table 6 shown convenience positively influence consumer shopping behaviour as $(t$-value $=3.042, p$-value $=0.001)$ and hypotheses $\mathrm{H}_{1}$ supported. CPI significantly mediates between convenience and online shopping behaviour as $(t$-value $=2.994, p$-value $=0.002)$ and supported $\mathrm{H}_{2}$. Product variety significantly influence on online 
shopping behaviour as $(t$-value $=3.881, p$-value $=0.000)$ and hypotheses $\mathrm{H}_{3}$ supported. CPI significantly mediates between product variety and online shopping behaviour as $(t$-value $=2.448, p$-value $=0.014)$ and $\mathrm{H}_{4}$ supported. Privacy risk negatively influence on online shopping behaviour $(t$-value $=1.860, p$-value $=0.032)$ and hypotheses $\mathrm{H}_{5}$ supported. CPI significantly mediates between privacy risk and online shopping behaviour as $(t$-value $=2.097, p$-value $=0.036)$ and supported $\mathrm{H}_{6}$. Product risk negatively influence on online shopping behaviour $(t$-value $=1.816, p$-value $=0.035)$ and hypotheses $\mathrm{H}_{7}$ supported. CPI significantly mediates between product risk and online shopping behaviour as $(t$-value $=2.215, p$-value $=0.026)$ and supported $\mathrm{H}_{8}$. CPI is a significant indicator of online shopping behaviour $(t$-value $=3.210$, $p$-value $=0.001)$ thereby supported hypotheses $\mathrm{H}_{9}$.

\section{Discussion}

The objective of this research is to examine the influence of product benefits and product risk on online shopping behaviour with the mediating role of consumer purchase intention. This study is cross sectional and quantitative in nature. Convenience has a significant and increasing influence on online shopping behaviour. The findings are consistent with Rehman (2018) that convenience plays a crucial role in determining online shopping behaviour. Moreover, product variety significantly boosts up online shopping behaviour. The results are similar with the study of Adnan (2014). Meanwhile, product risk has a significant influence over online shopping behaviour. The findings are in line with Bhatti, Saad and Gbadebo (2018) that product risk significantly decrease online shopping behaviour of customers. Moreover, privacy risk significantly decrease online shopping behaviour of customers. The results are similar with Bhatti, Saad and Gbadebo (2020); Rehman (2018) that privacy risk plays a vital role in reducing behaviour of customers to purchase goods online. Meanwhile, consumer purchase intention significantly increases the online shopping behaviour of customers. The findings are in line with Bhatti et al. (2020); He, Lu and Zhou (2008); Laohapensang (2009) that consumer purchase intention significantly influences customer behaviour. The results are also in line with TPB theory that intention significantly increases consumers behaviour (Ajzen, 1991). Consumer purchase intention significantly mediates between convenience, product variety, product risk, privacy risk, and online shopping behaviour. 


\section{Conclusion}

This study found two perceived benefits and two perceived risks to analyze the online shopping behavior of consumers. This study has contributed to e-commerce literature and general knowledge. In globalization, every organization tries to attract and retain customers in offline and online stores. There is limited research and literature on online shopping in Pakistan and as such, this topic was a challenge for researchers and scholars. Findings from the current study can help other researchers and vendors to understand how to enhance online shopping behavior of consumers by minimizing risks and ensuring that consumers' online shopping experience is more beneficial and better than offline shopping. This study focused on the perceived benefits i.e. convenience and product variety and perceived risks i.e. product risk and privacy risk. This study concluded that privacy and product risk are important concerns and it is essential to minimize these risks to assist consumers in making them feel safe when they conduct online shopping or transactions.

\section{Theoretical and Practical Contributions}

The current study contributed in theoretical terms by considering perceived benefits (convenience and product variety), perceived risks (product risk and privacy risk), and consumer purchase intention to measure online shopping behavior in light of TPB theory. TPB theory is the best theory to measure the behavior of consumers. TPB theory focuses on subjective norms, attitude, perceived behavioral control, and consumer purchase intention to measure online shopping behavior. This study incorporated perceived risks and perceived benefits to measure online shopping behavior in light of the TPB theory. In terms of its practical contribution, online retailers can benefit from this study by focusing on perceived benefits and perceived risks to enhance online shopping behavior.

\section{Limitations and Recommendations}

This study also has some limitations that need to be dealt with in future studies. This study was conducted in Gujranwala, Pakistan. Future studies can be conducted in other cities and countries in developing and developed countries. This study focused on a few 
factors. Future research can focus on other factors like convenience risk, non-delivery risk, social risk, physiological risk, perceived risk including perceived benefits of online shopping (behavior, adoption, and intention). Furthermore, attitude, trust, and social media can be used as a mediator/moderator between perceived risk and online shopping (behavior, adoption, and intention). Social exchange theory can be employed in future research to study the relationship between perceived risk and online shopping.

\section{References}

Adnan, H. (2014). An analysis of the factors affecting online purchasing behavior of Pakistani consumers. International Journal of Marketing Studies, 6(5), 133.

Ahmad, S. (2002). Service failures and customer defection: A closer look at online shopping experiences. Managing Service Quality: An International Journal, 12(1), 19-29.

Aijaz, H., \& Butt, F. S. (2009). Barriers in the development of electronic commerce: A study of Pakistani environment (Unpublished Master Thesis). Jonkoping International Business School, Jonkoping University, Pakistan.

Ajzen, I. (1985). From intentions to actions: A theory of planned behavior. Action control (pp. 11-39): Springer.

Ajzen, I. (1991). The theory of planned behavior. Organizational Behavior and Human Decision Processes, 50(2), 179-211.

Bashir, R., Mehboob, I., \& Bhatti, W. K. (2015). Effects of online shopping trends on consumer-buying behavior: An empirical study of Pakistan (Unpublished Master Thesis).

Bauer, R. A. (1960). Consumer behavior as risk taking. Paper presented at the Proceedings of the 43rd National Conference of the American Marketing Assocation, Chicago, Illinois.

Bhatti, A., Saad, S., \& Gbadebo, S. M. (2018). Convenience risk, product risk, and perceived risk influence on online shopping: Moderating effect of attitude. International Journal of Business Management, 3(2), 1-11.

Bhatti, A., Saad, S., \& Gbadebo, S. M. (2020). Moderator trust, subjective norms influence risk and online shopping behavior of consumers. International Journal of Science \& Technology Research, 9(1), 627-641. 
Bhatti, A. (2018a). Consumer purchase intention effect on online shopping behavior with the moderating role of attitude. International Journal of Academic Management Science Research, 2(7), 44-50.

Bhatti, A. (2018b). Factors effecting consumer purchase intention with the mediating role of corporate social responsibility in Pakistan. International Journal of Academic Management Science Research, 2(8), 30-37.

Bhatti, A. (2018c). Sales promotion and price discount effect on consumer purchase intention with the moderating role of social media in Pakistan. International Journal of Business Management, $3(4), 50-58$.

Bhatti, A., Saad, S., \& Gbadebo, S. M. (2018a). Convenience risk, product risk, and perceived risk influence on online shopping: Moderating effect of attitude. International Journal of Business Management, 3(2), 1-11.

Bhatti, A., Saad, S., \& Gbadebo, S. M. (2018b). The effect of financial risk and convenience risk on online shopping behavior with the moderating role of trust. International Journal of Academic Management Science Research, 2(8), 38-42.

Brüseke, L. (2016). The influence of privacy perceptions on online shopping behavior: A comparison between millennials and baby boomers. University of Twente.

Chakraborty, D. (2016). Factors affecting consumer purchase decision towards online shopping: A study conducted in Gangtok, Sikkim. Adarsh Business Review, 3(1), 11-18.

Chaudary, S., Rehman, M. A., \& Nisar, S. (2014). Factors influencing the acceptance of online shopping in Pakistan. The Lahore Journal of Business, 3(1), 75-97.

Chen, C.-H., \& Zimitat, C. (2006). Understanding Taiwanese students' decision-making factors regarding Australian international higher education. International Journal of Educational Management, 20(2), 91-100.

Chih, W., \& Tang, T.-W. (2005). The role of trust in customer online shopping behavior: Perspective of technology acceptance model. North American Association for Computational, Social and Organizational Science.

Chin, W. W. (1998). The partial least squares approach to structural equation modeling. Modern Methods for Business Research, 295(2), 295-336. 
Clemes, M. D., Gan, C., \& Zhang, J. (2014). An empirical analysis of online shopping adoption in Beijing, China. Journal of Retailing and Consumer Services, 21(3), 364-375.

Crespo, A. H., del Bosque, I. R., \& de los Salmones Sanchez, M. G. (2009). The influence of perceived risk on Internet shopping behavior: A multidimensional perspective. Journal of Risk Research, 12(2), 259-277.

Dai, B., Forsythe, S., \& Kwon, W.-S. (2014). The impact of online shopping experience on risk perceptions and online purchase intentions: Does product category matter? Journal of Electronic Commerce Research, 15(1), 13.

Dost, B., Khyzer, M., Illyas, M., \& Abdul Rehman, C. (2015). Online shopping trends and its effects on consumer buying behavior: A case study of young generation of Pakistan. NG-Journal of Social Development, 417(3868), 1-22.

Dowling, G. R., \& Staelin, R. (1994). A model of perceived risk and intended risk-handling activity. Journal of Consumer Research, 21(1), 119-134.

Fornell, C., \& Larcker, D. F. (1981a). Evaluating structural equation models with unobservable variables and measurement error. Journal of Marketing Research, 18(1), 39-50.

Fornell, C., \& Larcker, D. F. (1981b). Evaluating structural equation models with unobservable variables and measurement error. Journal of Marketing Research, 39-50.

Gregoire, C. (2013). Retail therapy: One in three recently stressed Americans shops to deal with anxiety. The Huffington Post. Retrieved from http://www. huffingtonpost. com/2013/05/23/ retail-therapy-shopping_n_3324972. html.

Hair, J. F., Black, W., Babin, B., \& Anderson, R. (2010). Multivariate data analysis. Vectors, 8(2), 125-136.

Hair, J. F., Ringle, C. M., \& Sarstedt, M. (2013). Partial least squares structural equation modeling: Rigorous applications, better results and higher acceptance. Thousand Oaks: Sage Publications

Hair Jr, J. F., Hult, G. T. M., Ringle, C., \& Sarstedt, M. (2013). A primer on partial least squares structural equation modeling (PLS-SEM). Thousand Oaks, CA.: Sage Publications.

Hair Jr, J. F., Hult, G. T. M., Ringle, C., \& Sarstedt, M. (2016). A primer on partial least squares structural equation modeling (PLS-SEM). Thousand Oaks: Sage Publications.

He, D., Lu, Y., \& Zhou, D. (2008). Empirical study of consumers' purchase intentions in $\mathrm{C} 2 \mathrm{C}$ electronic commerce. Tsinghua Science and Technology, 13(3), 287-292. 
Hidayanto, A. N., Saifulhaq, H., \& Handayani, P. W. (2012). Do consumers really care on risks in online shopping? An analysis from Indonesian online consumers. Paper presented at the 2012 IEEE International Conference on Management of Innovation and Technology (ICMIT).

Jayawardhena, C., Tiu Wright, L., \& Dennis, C. (2007). Consumers online: Intentions, orientations and segmentation. International Journal of Retail \& Distribution Management, 35(6), 515-526.

Kim, D., \& Ammeter, A. P. (2018). Shifts in online consumer behavior: A preliminary investigation of the net generation. Journal of Theoretical and Applied Electronic Commerce Research, 13(1), 1-25.

Kim, D. J., Ferrin, D. L., \& Rao, H. R. (2008). A trust-based consumer decision-making model in electronic commerce: The role of trust, perceived risk, and their antecedents. Decision Support Systems, 44(2), 544-564.

LaMorte, W. W. (2016). The Theory of Planned Behavior. Retrieved from http://sphweb.bumc.bu.edu

Laohapensang, O. (2009). Factors influencing internet shopping behaviour: A survey of consumers in Thailand. Journal of Fashion Marketing and Management: An International Journal, 13(4), 501-513.

Mitchell, V.-W. (1999). Consumer perceived risk: Conceptualisations and models. European Journal of Marketing, 33(1/2), 163-195.

Moshrefjavadi, M. H., Dolatabadi, H. R., Nourbakhsh, M., Poursaeedi, A., \& Asadollahi, A. (2012). An analysis of factors affecting on online shopping behavior of consumers. International Journal of Marketing Studies, 4(5), 81.

Nielsen, A. (2008). Grocery store choice and value for money: A global nielsen consumer report. Technical Report, January.

Nunnally, J. (1978). Psychometric theory (2nd ed.). Hillsdale, New Jersey: McGraw-Hill.

Pakwired. (2017, July 20). EasyPaisa now lets users create mastercard credit card within seconds. Retrieved from http://parkwired.com

Pavlou, P. A., Liang, H., \& Xue, Y. (2006). Understanding and mitigating uncertainty in online environments: A principalagent perspective. MIS Quarterly, 31(1), 105-136.

Popli, A., \& Mishra, S. (2015). Factors of perceived risk affecting online purchase decisions of consumers. Pacific Business Review International, 8(2), 49, 58.

Qureshi, H. A., Fatima, R., \& Sarwar, A. (2014). Barriers to adoption of online shopping in Pakistan. Science International, 26(3).

Rehman, S.-u. (2018). Impact of financial risk, privacy risk, convenience, and trust on online shopping with mediating role of consumer 
purchase intention in Pakistan. International Journal of Academic Multidisciplinary Research (IJAMR), 2(8), 27-34.

Rehman, S.-u., Bhatti, A., Mohamed, R., \& Ayoup, H. (2019). The moderating role of trust and commitment between consumer purchase intention and online shopping behavior in the context of Pakistan. Journal of Global Entrepreneurship Research, 9(1), 43.

Rehman, S.-u., Mohamed, R., \& Ayoup, H. (2019). The mediating role of organizational capabilities between organizational performance and its determinants. Journal of Global Entrepreneurship Research, 9(1), 1-23. doi: 10.1186/s40497-019-0155-5

Roscoe, J. T. (1975). Fundamental research statistics for the behavioral sciences [by] John T. Roscoe.

Seiders, K., Berry, L. L., \& Gresham, L. G. (2000). Attention, retailers! How convenient is your convenience strategy? MIT Sloan Management Review, 41(3), 79.

Sin, L., \& Tse, A. (2002). Profiling internet shoppers in Hong Kong: Demographic, psychographic, attitudinal and experiential factors. Journal of International Consumer Marketing, 15(1), 7-29.

Suhan, J. (2015). Acceptance of online shopping in Bangladesh: Consumer's perspective. Journal of Business and Management (IOS-JBM), e-ISSN, 14-24.

Tanadi, T., Samadi, B., \& Gharleghi, B. (2015). The impact of perceived risks and perceived benefits to improve an online intention among generation-Y in Malaysia. Asian Social Science, 11(26), 226.

Thananuraksakul, S. (2007). Factors affecting online shopping behaviour: A study of Thai consumers. University of South Australia.

To, P.-L., Liao, C., \& Lin, T.-H. (2007). Shopping motivations on Internet: A study based on utilitarian and hedonic value. Technovation, 27(12), 774-787.

Van der Heijden, H., Verhagen, T., \& Creemers, M. (2003). Understanding online purchase intentions: Contributions from technology and trust perspectives. European Journal of Information Systems, 12(1), 41-48.

Wang, C. L., Zhang, Y., Ye, L. R., \& Nguyen, D.-D. (2005). Subscription to fee-based online services: What makes consumer pay for online content? Journal of Electronic Commerce Research, 6(4), 304.

Yousaf, U., Altaf, M., Sarwar, N., Hassan, S., \& Ali, S. (2012). Hesitancy towards online shopping, a study of Pakistani consumers. Management \& Marketing Journal, 10(2). 